\title{
A Comparative Account of Possession Expression in Tugen and Kiswahili
}

\author{
Prisca Jerono \\ Department of Kiswahili, Faculty of Arts, University of Nairobi, Nairobi, Kenya
}

Email address:

prisca1jerono2@gmail.com, prisca.jerono@uonbi.ac.ke

\section{To cite this article:}

Prisca Jerono. A Comparative Account of Possession Expression in Tugen and Kiswahili. International Journal of Language and Linguistics. Vol. 7, No. 2, 2019, pp. 55-62. doi: 10.11648/j.ij11.20190702.11

Received: January 21, 2019; Accepted: March 13, 2019; Published: April 10, 2019

\begin{abstract}
Ownership, kinship and whole/part relationships are possessive expressions in natural languages. Possession is distinguished between alienable and inalienable possession, depending on the semantic relationship between the possessor and possessum. Alienable possession is a contextually dependent semantic relationship, where the elements in the relationship do not show any semantic dependency, whereas inalienable possession is a permanent semantic relationship between the possessor and the possessum for example as used in the expression of body parts. Besides possession, languages also exploit possessive expressions to express non possessive relationships, for example, emotive states. This paper attempts to compare how possession is expressed in Tugen, a Southern Nilotic language of the Kalenjin macro language and Kiswahili, a Bantu language. It also seeks to show how alienable and inalienable possession is distinguished in the languages, if at all, as well as how possessive expressions are used to express other non possessive relationships in both languages. It also seeks to find out the role of definiteness in the semantic expression of possession. This paper shows that in spite of the differences in the two languages the expression of possession is somewhat similar. Tugen is a VSO language while Kiswahili is an SVO language. Tugen is a native language spoken in Baringo county of Kenya, while Kiswahili is an official and national language in Kenya.
\end{abstract}

Keywords: Alienable and Inalienable Possession, Nominal Possession, Verbal Possession, Definiteness, Possessor Chains

\section{Introduction}

Possession, in the context of linguistics is an asymmetric relationship between two constituents, the referent of one of which (the possessor) possesses (controls, rules over, has a part, has a relative etc.) the referent of the other (possessum) [1]. Possession as a semantic property is expressed in language through various grammatical structures. The term possession is more or less equivalent to ownership; whatever $\mathrm{X}$ is said to possess may be described as his property $[2,3]$. In language possession can be expressed within the noun phrase or the verb phrase. The linguistic expression of possession within a noun phrase can be viewed as one of the realizations of a broader concept of association or a relationship between two or more nouns. It distinguishes the meanings associated with possessive noun phrases as those of ownership of property, whole part relations including body parts and plants and kinship relations, which also cover blood or consanguineal relations [3]. In cases where possession is expressed within the verb phrase, various languages have a dedicated verb used to express the notion that something is owned by someone or the relationship between someone and something.

Possession expression within the noun phrase that is used to express whole part relations can also be delineated on the basis of whether the relationship is alienable or not. Alienability refers to the ability to terminate the relationship between the part and the whole. Inalienable possession sometimes is linked to inherent possession, where the kinship or body part relation cannot be mentioned without explicitly stating the possessor. Also some languages distinguish between things that can and cannot be possessed. The boundary between alienable and inalienable posssion and the categories of alienable possession differ from language to language [4]. In trying to investigate how possession is expressed, this paper attempts at comparing how possession is expressed in Kiswahili, a Bantu language and Tugen a Southern Nilotic language with a view to find out how if they belong to the same typology. The paper begins with a brief description of the two languages, then it embarks on 
describing the expression of nominal possession and how definiteness of nouns influence its expression if at all; the distinction between alienable and inalienable possession if there; verbal possession and how the possessive constructions are used to express other non possessive constructions. Finally, it concludes by showing the differences and similarities between the two languages in the expression of possession.

\subsection{Kiswahili and Tugen Languages}

Kiswahili, is a bantu language that is spoken in east and central Africa. In Kenya, Kiswahili is both an official and national language [5]. As an official and national language it is a compulsory and examinable subject in both primary and secondary schools and is also taught in tertiary and university education. As a Bantu language its nouns are gendered in terms of number and therefore classified into 18 classes that focus on the function rather than form. This is reflected on the basis of the grammatical markers or subject prefixes on verbs [6]. In possessive constructions, possessive pronouns and possessive prepositions are prefixed with class agreement markers. Unlike in English, the personal pronouns are not gendered in terms of masculinity or femininity.

Tugen on the other hand is one language within the Kalenjin group of languages. Kalenjin belongs to the southern Nilotic grouping of languages and is spoken in Baringo County of Kenya. Different from Kiswahili which is an SVO language, Tugen is a verb first language with the order of the arguments after the verb being relatively free. SVO order is reserved for focused constituents [7]. Tugen also does not have number classes, but number markers are suffixed on the nouns [8]. The nouns are also differentiated on the basis of definiteness/specificity with the definite form being unmarked. The numerical markers agree with the personal pronouns. The personal pronouns just like in Kiswahili are not marked for masculinity or femininity though a few nouns bear this feature.

\subsection{Possession in Noun Phrases}

Many languages use possessive NPs to express whole part relations or property and association in general. The same construction may also be used to express ownership of property or kinship terms [3]. In Kiswahili the expression of possession is done by the associative prepositional affix $-a$. The Kiswahili preposition is preceded by agreement markers depending on the noun class. 'This is seen below:

1(a) Ng'ombe w-a mama a-me-potea

SG.cow AGR-POSS mother AGR-ASP- lost

The cow of mother is lost

1(b) M-kono w-a mw-anamke ni m-refu CLF-hand AGR-POSS CLF-woman be AGR-long The hand of the woman is long

In the Kiswahili example, the associative marker is an independent word that comes between the possessum and the possessor. However, this marker is suffixed to the noun class agreement marker in this case as seen in 1(a) \& (b). In this association, the possessum comes before the possessor. In Tugen nominal possession is made of two or more NPs plus a possessive preposition $-a p$ (of). The preposition is suffixed to the possessum as in:

$\begin{array}{lll}\text { 2(a)Ka-bet } & \text { tee-ta-ap } & \text { chep-yos-e } \\ \text { TNS-lost } & \text { cow-SG.DEF-POSS } & \text { F-woman-SG.DEF }\end{array}$

The cow of the woman has gotten lost

$\begin{array}{lll}\text { 2(b)Koi } \quad \text { e-ut-ap } & \text { chep-yos-e } \\ \text { Long } & \text { hand-SG.DEF-POSS } & \text { F-woman-SG.DEF } \\ \text { The hand of the woman is long } & \end{array}$

From 2 we can see that the associative preposition is suffixed to the possessum. The possessum comes before the possessor.

In expressing alienable and inalienable possession the same associative preposition is used in both languages. Alienable possession is the kind of possession which can be terminated while inalienable possession is the kind of possession that cannot be terminated [9]. This is seen in 3:
3(a)Ki-jiti ch-a
m-toto
ki-me-kat-w-a
CLF-stick AGR-POSS CLF-child
AGR-ASP-cut-PASS-
FV

The stick of the child has been cut

$\begin{array}{llll}\text { 3(b) M-kono } & \text { w-a } & \text { u-na } & \text { maji } \\ \text { CLF-hand } & \text { AGR-POSS } & \text { AGR-have } & \text { water } \\ & \text { CLF-child } & \text { AGR }\end{array}$

The hand of the child is wet

$\begin{array}{llll}\text { 3(c)?Shemeji } & \text { w-a } & \text { baba } & \text { a-me-kuj-a } \\ \text { brother-in -law } & \text { AGR- } & \text { father } & \text { AGR-ASP- } \\ & \text { POSS } & & \text { come-FV }\end{array}$

Father's brother-in-law has come (The brother-in law of father has come)

In expressing alienable possession such as possession of property as in 3(a) and inalienable possession such as whole part relations and kinship relations, the same associative preposition $-a$ is used, however in kinship relations such as 3(c) the use of the reduced form of the possessive pronouns as a suffix is more preferable certain relations. In this case the more acceptable way would be the use of the reduce form $-k e$ of the personal pronoun yake as in $3(\mathrm{~d})$.

$\begin{array}{lll}\text { 3(d)Baba-ke } & \text { Juma } & \text { a-me-kuj-a } \\ \text { Father-POSS } & \text { Juma } & \begin{array}{l}\text { AGR-ASP- } \\ \text { come-FV }\end{array}\end{array}$

Juma's father has come

On the other hand, in Tugen the expression of alienable and inalienable possession is seen below:

$\begin{array}{lll}\text { 4(a)Ka-ki-til } & \text { keet-it-ap } & \text { Kip-rop } \\ \text { TNS-PASS-cut } & \text { tree-SG.DEF- } & \text { M-rop }\end{array}$

The tree of Kiprop has been cut

$\begin{array}{llll}\text { 4(b)Tiny-ei } & \text { tis-ye } & \begin{array}{l}\text { kuut-it-ap } \\ \text { mouth- }\end{array} & \text { laakw-ee } \\ & \text { mark- } & \text { SG.DEF- } & \text { child- } \\ \text { Have-ASP } & \text { SG.DEF } & \text { POSS } & \text { SG.DEF }\end{array}$

The mouth of the child has a mark 


\section{4(c)Ka-ko-nyo kwan-da-ap}

\section{The father of Cherono has come}

In 4 it can be seen that there is no difference in expressing the possession of property, whole part relations or kinship in Tugen. The same prepositional suffix $-a p$ is used and is suffixed to the possessum.

\subsubsection{Possessive Pronouns}

Possession in language can be also done within the NP through the use of possessive pronouns. These pronouns are based on personhood and modify the possession of a noun. In Kiswahili these possessives are:

$\begin{array}{lll}1 & 2 & 3 \\ \text {-angu (my) } & \text {-ako (your) } & \text {-ake (his/hers) } \\ \text {-etu (our) } & \text {-enu (your) } & \text {-ao (their) }\end{array}$

In Kiswahili, these possessives are adjectives, which modify the noun. The possessives are affixed with agreement prefixes depending on noun class. When used to alienable and inalienable possession these possessives show the following variations:

$\begin{array}{lll}5(\mathrm{a}) \text { Kalamu } & \text { y-angu } & \text { i-me-anguk-a } \\ \text { Pen } & \text { AGR-my } & \text { AGR-ASP-fall-FV }\end{array}$

My pen has fallen

$\begin{array}{ll}\text { 5(b)M-guu w-ako } & \text { u-me-teguk-a } \\ \text { CLF-leg AGR-your } & \text { AGR-ASP-sprain-FV }\end{array}$

Your leg has sprained

5(c)A-me-it-w-a

na mama y-ake

3SG-ASP-call-PASS-FV by mother 3SG-his/her

He has been called by his/her mother

In $5(\mathrm{a}-\mathrm{c})$ the possessor is juxtaposed to the possessum, whereby the possessor follows the personal pronoun. However, in 5(c) where the inaelinable possession of kinship relations is involved, there is the option of using the reduced form of the possessor $-k e$ as a suffix to the possessum in this case mamake. This use of the reduced adjective however is restricted more to the singular form than to the plural form except in some exceptional instances as seen in 6 in Table 1:

Table 1. Possessive Adjectives in Kiswahili.

\begin{tabular}{|c|c|c|c|c|c|c|c|}
\hline Relation & -angu & -ako & -ake & -etu & -enu & -ao & gloss \\
\hline 6(a)dada & dadangu & dadako & dadake & ?dadetu & ?dadenu & ?dadao & sister \\
\hline (b)kaka & kakangu & kakako & kakake & ?kaketu & ?kakenu & kakao & brother \\
\hline d)shangazi & shangazi yangu & shangazi yako & shangaziye & shangazi yetu & shangazi yenu & shangazi yao & aunt \\
\hline e)mjomba & mjombanu & mjombao & mjombake & mjomba wetu & mjomba wenu & mjombao & uncle \\
\hline f)mwana & mwanangu & mwanao & mwanawe & mwanetu? & mwana wenu & mwanao & child \\
\hline g) nyanya & nyanyangu & nyanyako & nyanyake & nyanya yetu & nyanya yenu & nyanya yao & grandmother \\
\hline
\end{tabular}

In 6 above, the singular form of the possessive pronoun allows its reduced form to be suffixed to the possessor except 6(d) which disallows the reduced form in the first and second person but allows it in the third person in the relation of shangazi-ye 'his/her aunt'. The plural form of the possessive pronoun disallows the use of the reduced except in a few relations such in the third person such as 6 (c) mama-o 'their mother', 6(e) mjomba-o 'their uncle' and 6 (f) mwana-o 'their child'. The reason behind such exceptions is not clear.

The possessive pronouns in Tugen are preceded in their full form by the prefix ne- 'is' which is a focus marker but in possession within the noun phrase the focus marker is omitted and the pronouns are as follows:

$\begin{array}{lll}1 & 2 & 3 \\ \text { nyu (my) } & \text {-ng'ung' (your) } & \text {-nyi (his/hers) } \\ \text { nyo (our) } & \text {-ng'wong (your) } & \text {-nywa (their) }\end{array}$

In possessive constructions these personal pronouns appear as in 7 below:
7(a)Ka-ki-bat
mbar-e-nywa
TNS-PASS-plough farm-SG.DEF-their
Their farm has been ploughed

7(b)ø-am-ei

3SG-eat-ASP

His/her nose hurts ser-u-nyi nose-SG.DEF-his/hers

$\begin{array}{lll}7(\mathrm{c}) \mathrm{Ni} & \text { ko } & \text { tupch-e-ng'wong' } \\ \text { This } & \text { COP } & \text { brother-SG.DEF-your }\end{array}$

This is your brother

In Tugen all these possessives pronouns are suffixed to the possessum irrespective of the type of relationship whether alienable or inalienable.

Possession may be marked in many ways such as a simple juxtaposition of nouns, a possessive case, a construct case by possessor agreement on the possessum or adpositions [1]. Going by the analysis of the two languages we can see that in Kiswahili, the marking of possession is partially through the use of possessive pronouns on the possessum. The possessive pronoun is added as a suffix to the possessum only in nouns that involve a few kinship relations. The other means is done by juxtaposition where the possessor appears after the possessum. Where possessive marking is done through the possessive preposition, the preposition associates the possessum to the possessor.

In Tugen the formal marking of possession is through the possessive pronouns and similar to Kiswahili the possessive pronoun is suffixed to the possessum. This suffixation is done for all types of possession. In the use of the possessive preposition $-a p$, this is also suffixed on the possessum. The possessum precedes the possessor in all kinds of possession. Unlike Kiswahili, where the preposition is an independent word, the Tugen preposition is a suffix. 


\subsubsection{Possession and Definiteness}

Nouns in Tugen unlike Kiswahili are marked for definiteness/specificity morphologically. Tugen nouns come in two forms the indefinite and definite [7]. The definite form is unmarked. The indefinite form has only number suffixes and most cases can remain as roots while the definite form has both the number and/or definite suffixes. The aspect of definiteness introduces the use of another possessive preposition into the expression of possession in Tugen. The expression of possession for the indefinite and definite is differentiated on the basis of the preposition used where for the definite the preposition $-a p$ is used while for the indefinite the preposition $p o$ is used. The preposition po 'of' is used as a word except in certain circumstances where it is used as a suffix. This word is also used to express predicate possession. When used within the nominal possession it associates possessor to possessum. It's use is only restricted to indefinite nouns as seen below:

$\begin{array}{llll}\text { 8(a)Ka-a-ro } & \text { aran } & \text { po } & \text { chi } \\ \text { TNS-1SG-see } & \text { goat.SG.INDF } & \text { POSS } & \text { person.INDF } \\ \text { I saw someone's goat } & & \end{array}$

$\begin{array}{llll}\text { 8(b)Ka-a-til } & \text { keel } & \text { po } & \begin{array}{l}\text { laakw-a } \\ \text { child- }\end{array} \\ \begin{array}{l}\text { TNS-1SG- } \\ \text { cut }\end{array} & \text { leg.SG.INDF } & \text { POSS } & \text { SG.INDF }\end{array}$

I have cut a leg of a child

8(c)Ko-kiyoon kwan-po1

chi

\section{TNS-PASS-}

father.SG.INDF-

chase POSS

person.INDF

\section{Someone's father was chased}

As can be seen above the preposition po is used specifically to refer to a possessive relation for the indefinite form of the noun. This preposition comes between the possessum and the possessor and can become a suffix in possessive relations involving kinship terms as seen in $8(\mathrm{c})$. The possessum comes before the possessor and both the possessor and the possessor are in the indefinite form as seen above. When used with the definite form of the noun the construction becomes unacceptable as in 9 :

$\begin{array}{llll}\text { 9(a)*I-chut-i } & \text { e-ut } & \text { po } & \text { chi-to } \\ \text { 3SG-pull- } & \text { hand- } & \text { POSS } & \text { person- } \\ \text { ASP } & \text { SG.DEF } & & \text { SG.DE }\end{array}$

He is pulling the hand of a person

$\begin{array}{lll}\text { 9(b)*Ka-ki-al } & \text { ngor } \quad \text { po } & \text { laakw-ee } \\ \text { TNS-PASS-buy } & \text { cloth-SG.INDF POSS } & \text { child-SG.DEF }\end{array}$

As it can be seen from 9 above the constructions are not acceptable where both the possessor and possessum are in the indefinite and also where the possessor is definite while the possessum is indefinite. The structural relations of expressing alienable and inalienable possession through the use of both the prepositions of -ap and po differ. Alienable possession in Tugen demands that the possessum that is suffixed $-a p$ be in the definite form while the possessor can be in the definite or

1 This due to vowel harmony and assimilation becomes kwombo. the indefinite form as seen below:

$\begin{array}{lll}\text { 10(a)Ko-ø-alda } & \text { mbar-et-ap } & \text { Kip-koech } \\ \text { TNS-3SG-sell } & \text { farm-SG.DEF-POSS } & \text { M-koech }\end{array}$

He sold Kipkoech's farm

10(b)Ka-ki-eny moi-t-ap tany

TNS-PASS-slaughter calf-SG.DEF-POSS cow.SG.DEF

The calf of a cow was slaughtered.

$\begin{array}{lll}\text { 10(c)*Ka-i-tyaar } & \text { keel-yen-ap } & \text { chi } \\ \text { TNS-3SG-kick } & \text { leg-PL-INDF-POSS } & \text { person.INDF }\end{array}$

He kicked legs of someone

In 10 (a-b) the possessive prepositions - ap is suffixed to a definite possessum, while the possessor can be definite or indefinite, and the constructions are acceptable but -ap cannot be suffixed to an indefinite possessum as can be seen in 10(c). However, it may be acceptable in some inalienable possessions as seen in 11:

\begin{tabular}{|c|c|}
\hline 11(a)ø-tinye-i & warw-ap \\
\hline 3SG-has- ASP & lamb-SG.INDF-POSS \\
\hline
\end{tabular}

He/she has a lamb of a sheep

$\begin{array}{lll}\text { 11(b)Ka-i-tun } & \text { kaam-ap } & \text { chi } \\ \text { TNS-3SG- } & \text { mother.SG.INDF- } & \text { person.INDF } \\ \text { marry } & \text { POSS } & \end{array}$

\section{He married someone/s mother}

In 11(a-b) the possessum and the possessor are both indefinite and the possessive preposition -ap is suffixed to the possessum contrary to what is expected. This situation only occurs in possessive relations involving some kinship and part -whole relations. If we segregate whole part and kinship possession in the use of both the prepositions - ap and po the situation obtains as follows:

$\begin{array}{lll}\begin{array}{l}\text { 12(a)Ka-ki- } \\ \text { chuut }\end{array} & \text { sarur-yet-ap } & \text { tany } \\ \text { PST-PASS-pull } & \begin{array}{l}\text { tail-SG.DEF- } \\ \text { POSS }\end{array} & \text { cow.SG.INDF }\end{array}$

The tail of a cow was pulled

12(b)*Ka-ki-

chuut sarur-ap tany

PST-PASS-pull tail.SG.INDF-POSS cow.SG.INDF

A tail of a cow was pulled

12(c)Ka-ki-

chuut sarur po tany

PST-PASS- tail.SG.INDF POSS cow.SG.INDF

pull

A tail of a cow was pulled

13(a)Katuyen

PST-meet mother.SG.INDF-

I met a mother of a chief

kaam-ap

kirwogin

13(b)*Ka-

tuyen

kaam

po

kirwogin

chief.SG.INDF 
PST-meet mother.SG.INDF POSS chief.SG.INDF

I met a mother of a chief

In 11 the inalienable possession involved is that of wholepart relation. In this kind of relationship, the use of the possessive preposition -ap is allowed when the possessum is definite as seen in 11(a) and disallowed when it is indefinite as seen in 10(b). The use of po when the possessum in indefinite is acceptable as in 11(c). In kinship relations in 12 the suffixation of $-a p$ on the possessum has mixed results for the indefinite possessum. In 12 (a) the possessum is in the definite form and as expected the suffixation of $-a p$ is allowed. Different from the situation in 11(b) of the whole part relation, the suffixation of the possessive -ap is allowed even when the possessum is in the indefinite form in 12(a). However the use of $p o$ for the indefinite possessum is not acceptable in the kinship relation in 12(b). This however seems to be the exception in this example, for in most cases there is no variance in the use of po in inalienable and alienable possession for indefinite noun phrases as seen in 13. In the expression of ownership through this preposition, po associates possessor and possessum as an independent word.

14(a)Ka-ki- ko po chi
put

PST-PASS- house.SG.INDF POSS person.SG.INDF

Someone's house was demolished

$\begin{array}{lll}\text { 14(b)Ki-nyo-i kiin-a po } & \text { tany } \\ \text { PST-treat-ASP teat-SG.INDF POSS } & \text { cow.SG.INDEF } \\ \text { A teat of a cow is being treated } & \end{array}$

\subsubsection{Iconicity and Economic Motivation in Possession}

According to the iconicity principle, two concepts are close to the extent that they can be perceived as inseparable (e.g there is a closer conceptual link between a possessor and an inalienably possessed object than between a possessor and an alienably possessed object [10]. The linguistic distance between expressions corresponds to the conceptual distance between them. By looking at the examples from the two languages the linguistic distance between the possessor and possessum in an alienably possessed object in Kiswahili is longer in comparison to an inalienable object that expresses some kinship relations. In Tugen the conceptual distance between alienable and inalienable objects and the possessor is similar, therefore, the iconicity principle does not offer much in explaining the differences in the relationships. However, this can be explained by the economic motivation and frequency of occurrence [11]. Inalienable nouns often occur as possessed nouns while inalienable nouns rarely occur as possessed nouns "Hence, upon hearing an alienable noun hearers can predict that it will occur as a possession in a possessive construction and overt marking is relatively redundant, p. 3". In terms of the economic motivation and frequency of occurrence in Kiswahili it can be seen that this situation obtains in the sense that no possessive marking is required for possessums that are inalienable as in the following example:

$\begin{array}{ll}\text { 15(a)Kalamu } & \text { i-me-potea } \\ \text { Pen.SG } & \text { AGR-ASP-lost }\end{array}$

The pen is lost

$\begin{array}{lll}\text { 15(b)Kalamu } & \text { y-angu } & \text { i-me-potea } \\ \text { Pen.SG } & \text { AGR-my } & \text { AGR-ASP-lost } \\ \text { My pen is lost } & & \end{array}$

$\begin{array}{ll}\text { 15(c)Pua } & \text { li-na-uma } \\ \text { Nose.SG } & \text { AGR-TNS-ache }\end{array}$

The nose is aching

$\begin{array}{lll}\text { 15(d)M-toto } & \text { a-na-mw-ita } & \text { mama } \\ \text { CLF-child } & \text { AGR-TNS-3SG-call } & \text { mother.SG }\end{array}$

The child is calling the mother

In 15(a) the construction is silent as regards to the ownership of the pen. Such a construction does not express possession on its own and for possession to be expressed then the possession has to be expressly shown through the preposition $-a$ as in kalamu yangu 'my pen' or kalamu ya Juma 'Juma's pen'. This makes the expression of alienable possession in Kiswahili to be inherent. However, in terms of inalienable possession, the whole part and kinship relations are seen as possessums and even when possessors are not expressed the default possessor is taken to be the speaker. The possessors in 15(c) an 15(d) are taken to be the speaker and the subject respectively and for this reason zero coding is used.

With regard to possession in Tugen possession the situation below obtains:

$\begin{array}{lll}\text { 16(a)Ka-alda } & \text { teeta } & \text { Kip-koech } \\ \text { PST-sell } & \text { cow.SG.DEF } & \text { M-koech }\end{array}$

Kipkoech sold the cow

$\begin{array}{lll}\text { 16(b)Ka-til } & \text { keet-it } & \text { Kip-koech } \\ \text { PST-cut } & \text { tree-SG.DEF } & \text { M-Koech }\end{array}$

Kipkoech has cut the tree

$\begin{array}{lll}\text { 16(c)Ka-til } & \text { suume-k } & \text { Chee-rono } \\ \text { PST-cut } & \text { hair-DEF } & \text { F-rono }\end{array}$

\section{Cheerono has cut the hair}

In 16(a) in as much as the noun teeta 'cow' does not portray ownership the expression implies that the cow belongs to Kipkoech. However this meaning is not implied in 16(b) where a tree is not possessed. In Tugen, the material culture such as livestock and houses are possessable so they behave similarly to the inalienable constructions such as 16(c) which though unmarked implies possession. In this sense the frequency of occurrence and economic motivation also explains this for there can be inherent possession in a language without alienable/inalienable distinction where there is a possessive construction that requires some items to be possessed and another type of construction that does not impose such requirements, [9]. Tugen for this reason does display inherent possession for items that are not possessable. 


\subsubsection{Possessor Chains}

Another way of expressing nominal possession is through possessor chains. Possessor chains refers to nested possessive relationships. In language there can be multiple possession or recursive possession. In multiple possessions, a possessive construction is nested with one another possessive construction where the innermost possession is identical for the two possessive constructions but the two stand in different relations with different possessors. The recursive possession is where one possessive construction is nested with another possessive construction and the possessive relation is linked to one possessor. In the recursive expression the possessive preposition associates the possessum to the possessors in the immediate and final positions in Kiswahili and Tugen. In both languages the intermediate possessor is expressed by the noun which may be modified by the possessive pronoun and appears at the end of the chain. In Kiswahili the $-a$ preposition associates the relation and changes form depending on the number agreement marker. The preposition $-a p$ in suffixed to the possessum and the possessor as seen in 17 .

$\begin{array}{llllll}\text { 17(a)Nyumba } & \text { y-a } & \text { shangazi } & \text { w-a } & \text { m-ke w-angu } \\ \text { House.SG } & \text { AGR- } & & \text { aunt.SG } & \text { AGR- } & \text { CLF- AGR- } \\ & \text { POSS } & & \text { POSS } & \text { wife my }\end{array}$

The house of the aunt of my wife

$\begin{array}{lll}\text { 19(a)Ka-a-tech-e } & \text { ko } & \text { ne } \\ \text { PST-1SG-build-ASP } & \text { house.SG.INDF } & \text { FOC } \\ \text { I was building a house that belongs to the child of my wife. }\end{array}$

Where the ultimate noun is in the indefinite, the focus marker ne and the possessive po also associates the possessor to the intermediate possessor as seen in 19(a). In case all the NPs are in the indefinite the focus marker and $p o$ associates all the relationships as in 20(b). The relationships can be

$\begin{array}{llllll}\text { 17(b)Nyumba } & \text { y-a } & \text { m-toto } & \text { w-a } & \text { m-toto } & \text { w-angu } \\ \text { House.SG } & \text { AGR- } & \text { CLF- } & \text { AGR- } & \text { CLF- } & \text { AGR- } \\ & \text { POSS } & \text { child } & \text { POSS } & \text { wife } & \text { my }\end{array}$

The house of the child of my child

$\begin{array}{lll}\text { 18(a)Koot-ap } & \text { kwan-da-ap } & \text { cheep-yos-e-nyu } \\ \text { House.SG.DEF- } & \text { father-SG.DEF- } & \text { F-woman- } \\ \text { POSS } & \text { POSS } & \text { SG.DEF-my }\end{array}$

The house of the father of my wife

$\begin{array}{lll}\text { 18(b)Ko-ot-ap } & \text { laakw-et-ap } & \text { laakw-e-nyu } \\ \text { House-SG.DEF- } & \text { child-SG.DEF- } & \text { child-SG.DEF- } \\ \text { POSS } & \text { POSS } & \text { my }\end{array}$

The house of the child of my child.

In both $17 \& 18$ the possessum begins followed by the ultimate possessor with intermediate possessors at the end. In cases where the noun is in the indefinite form, the possession relation is expressed by focus where the focus marker ne (sg) and che (pl) serve to highlight the property and the possession preposition $p o$ is used to associate it to the possessor. In this case the ultimate possessor is in the definite form with the preposition $-a p$ associating it to the intermediate possessor which bears the pronominal possessive marker as a suffix. The intermediate possessor is also in the definite form as seen in 18 : extended by stacking ne po after each kind of relationship. In all cases ultimate ownership comes immediately after the possessum and the relationship between the intermediate possessor and the ultimate possessor become far removed as the nestling progresses. PST-PASS-cut hand-SG.INDF FOC POSS child-SG.INDF FOC POSS brother-SG.DEF-my A hand that belongs to a child that belongs to my brother's was cut

$\begin{array}{llllllll}\text { 20(b)Ko-il } & \text { morn-a } & \text { ne } & \text { po } & \text { keel } & \text { ne } & \text { po } & \text { moi } \\ \text { PST-break } & \text { finger-SG.INDF } & \text { FOC } & \text { POSS } & \text { leg.SG.INDF } & \text { FOC } & \text { POSS } & \text { calf.SG.INDF }\end{array}$

\section{Predicate Possession}

Predicate possession is associated with the verbs HAVE and BELONG which is also known as indefinite and definite possession, [14]. Predicate possession is also investigated as non verbal predication, $[12,13]$. In languages, non verbal predicates vary according to (i) morphosyntactic category of the predicate phrase (ii) the predication type of the clause (ascriptive, equative, presentative) (iii) the kinds of verbal element such as copulas (if any) that occur in them and their semantic contribution [14]. The languages under discussion have different ways of expressing the predicate possession. Kiswahili, uses the verbal morpheme $-n a$ to express HAVE possession. This morpheme is prefixed with agreement markers and/or negation depending on noun class. This verb also expresses the present tense as seen below:
21(a)Mw-alimu
a-na
CLF-teacher
AGR-TNS.have
gari
Teacher has a car

$\begin{array}{lll}\text { 21(b)Mw-alimu } & \text { ha-na } & \text { kalamu } \\ \text { CLF-teacher } & \text { 3.NEG-TNS.have } & \text { pen }\end{array}$

The teacher does not have a pen

$\begin{array}{lll}\text { 21(a)Mw-alimu } & \text { a-na } & \text { gari } \\ \text { CLF-teacher } & \text { AGR-TNS.have } & \text { car }\end{array}$

Teacher has a car 


$\begin{array}{lll}\text { 21(b)Mw-alimu } & \text { ha-na } & \text { kalamu } \\ \text { CLF-teacher } & \text { 3.NEG-TNS.have } & \text { pen } \\ \text { The teacher does not have } \text { a pen } & \\ & & \\ & \\ \text { 21(c)Ki-sima } & \text { ki-na } & \text { maji } \\ \text { CLF-well } & \text { AGR-TNS.have } & \text { water }\end{array}$

The well has water.

The use of $-n a$ in Kiswahili expresses possession both permanent and temporary as well as alienable and inalienable possession. na can also be used as a preposition to express possession in the past and future tense as well as accompaniment or with. In this function the verb is preceded by an auxiliary verb as seen in 22 . However, it does not express location.

$\begin{array}{llll}22(\mathrm{a}) \mathrm{Mw}-\mathrm{alimu} & \text { a-li-kuwa } & \text { na } & \begin{array}{l}\text { mw- } \\ \text { anafunzi }\end{array} \\ \text { CLF-teacher } & \text { AGR-TNS-be } & \text { with } & \text { CLF-student } \\ \text { The teacher was with the student } & & \end{array}$

The teacher was with the student

$\begin{array}{llll}\text { 22(b)Juma } & \text { a-li-kuwa } & \text { na } & \text { kalamu } \\ \text { Juma } & \text { AGR-TNS-be } & \text { have } & \text { pen } \\ \text { Juma had a pen } & & & \end{array}$

The belong possession in Kiswahili is also expressed by the preposition $-a$ which comes before the possessor in a non predicate possession specifically involving the use of the copula as in 23 :

\begin{tabular}{lllll}
$\begin{array}{l}\text { 23(a)Ki- } \\
\text { tabu }\end{array}$ & h-iki & ni & ch-a & mw-alimu \\
CLF-book & AGR-this & COP & AGR-POSS & CLF-teacher \\
\multicolumn{7}{l}{$\begin{array}{l}\text { This book belongs to the teacher } \\
\text { 23(b)H-ii }\end{array}$ ni } & y-a & wa-toto & w-angu \\
AGR-this & COP & AGR- & CLF- & AGR-my \\
& & POSS & child & AG-my
\end{tabular}

This belongs to my children

In the use of $-a$ preposition there are no differences between the nominal and predicate possession.

In Tugen have and belong possession is expressed by the verbs tinye and po respectively just like in Keiyo [15]. The verb tinye can be prefixed with person, tense and aspect markers as seen in 23:

$\begin{array}{llll}\text { 24(a)Tinye-i } & \begin{array}{l}\text { laag-ok } \\ \text { child- }\end{array} & \text { aeng' } & \begin{array}{l}\text { konetin-det } \\ \text { teacher- }\end{array} \\ \text { Have-ASP } & \text { PL.DEF } & \text { two } & \text { SG.DEF }\end{array}$

The teacher has two children

$\begin{array}{lll}\text { 24(b)Ki-tinye } & \text { eu-n } & \text { aeng' } \\ \text { PST-have } & \text { hand-PL-INDF } & \text { two } \\ \text { It had two hands } & & \end{array}$

\section{Other uses of Possessive Markers}

In Kiswahili, the $-a$ preposition is also used for identification/specification. Some nouns are identified by the use of the $-a$ preposition as seen below:

27(a) Gari la moshi -train (a car with smoke)

27(b) Glasi ya maji -water glass

27(c)Barabara ya lami -tarmac road)
This is also the case with - ap in Tugen where some nouns are identified by the preposition as seen in:

$\begin{array}{ll}\text { 28(a) Tereet-ap peek } & \text { waterpot } \\ \text { 28(b) Koot-ap ngatutik } & \text { house of laws (parliament) }\end{array}$

The prepositions $-a$ in Kiswahili and -ap in Tugen are also used to show location as in:
29(a) Nyuma ya kiti
29(b) Juu ya meza
30(a) Batet-ap koot
30(b) Tait-ap biik
behind the chair
on top of the table
behind the house
in front of people

$P o$ in Tugen can be used as a preposition and a verb. In its use as a verb it expresses the belong possession. As seen in 1.2.2, po expresses nominal possession as a preposition. In predicate possession it is verb as seen below:

$\begin{array}{lll}\text { 25(a)Po laakw-eet } & \text { Ki-maru } \\ \text { Belong } & \text { child-SG.DEF } & \text { M-maru }\end{array}$

The child belongs to Kimaru.

$\begin{array}{lll}25(\mathrm{~b}) \mathrm{Po} & \text { ti-biik } & \text { ko-ot } \\ \text { Belong } & \text { girl-PL-DEF } & \text { house-SG.DEF }\end{array}$

The house belongs to the girls.

The use of po in the verbal possession can also be used with indefinite possessors and possessums but the meanings derived is that of general possession in abstract terms as in 25.

$\begin{array}{lll}26 . P o & \text { chi } & \text { tany } \\ \text { Belong } & \text { person.INDF } & \text { cow.INDF } \\ \text { A cow belongs to someone. } & \end{array}$

\section{Conclusion}

This paper set out to find out how two languages- a Bantu and a Nilotic language express both nominal and predicate possession. In nominal possession, the paper set to show alienable and inalienable possession is expressed as well as the differences that pertain between the two languages. This paper has found out that in Kiswahili, nominal possession is expressed via the preposition $-a$ which comes between the possessor and the possessum as an independent word. In Tugen the preposition $-a p$ is suffixed to the possessum to show nominal possession. The possessum is juxtaposed with the possessor with the possessum coming first. These prepositions are used for both alienable and inalienable possessions. However in Kiswahili, there is preference for the use of pronominal possessives to express kinship relations.

Tugen nouns unlike Kiswahili are marked for definiteness. This specification introduces the possessive preposition $p o$ which unlike $-a p$ is an independent word. However, this preposition is not used for inalienable possessions involving indefinite kinship terms.

Regarding the iconicity principle, it was found out that in Kiswahili the conceptual distance between the alienable and inalienable possession is similar except for inalienable possession where the distance is shorter for kinship terms. In Tugen there is no difference in conceptual distance between the alienable and inalienable possession. With regards to the 
economic motivation and frequency of occurrence, Kiswahili does apply this principle for possessums that are alienable for they are inherently possessed, however in inalienable possessums the possessors have to be coded. In Tugen, all possessable nouns whether alienable and inalienable apply this principle in having zero coding for possessums. In expressing possessive chains Kiswahili uses the $-a$ preposition while Tugen uses the -ap and po prepositions.

In predicate possession, Kiswahili uses the verbal morpheme $-n a$ to express HAVE possession and the preposition $-a$ for the belong possession. In Tugen the verb tinye is used for the HAVE possession in all tenses.. Po is also used for the BELONG possession for both definite and indefinite possessums. The possessive markers $-a$ and $-a p$ are also used in both languages for identification/specificity and location.From this analysis it is found that there are minimal differences in the expression of alienable and inalienable possession as well as predicate possession in Kiswahili and Tugen. It can be concluded that typologically the two languages are relatively similar in the expression of possession.

\section{References}

[1] Roberts, J. A (2015) Inalienable Possession in Amele: A Role and Reference Account. SIL International, SIL Electronic Working papers 2015-002.

[2] Lyons, J. (1977) Semantics Vol 2. Cambridge; Cambridge University Press.

[3] Aikhenvald, A. Y (2013) Possession and Ownership- A Cross Linguistic Perspective In Aikhenvald A. Y \&R. M. W. (eds) Dixon Possession and Ownership, Oxford, Oxford University Press.
[4] Rijn, V. M (2016) The grammaticalization of Possessive person marking; A Typolological Approach. Transactions of the Philological Society Vol 114:2 pp. 233-276.

[5] Republic of Kenya (2010) The Kenya Constitution. Nairobi; Government Printer.

[6] Mohamed, M. A. (2001) Modern Swahili Grammar. Nairobi, East African Educational Publishers.

[7] Jerono, P. (2012) Tugen Word order- A Minimalist Perspective, Macedonia EGALITE.

[8] Jerono, P. (2018) “Tugen Noun Classification" In Schroeder H. \& P. Jerono (eds) Nilo-Saharan Issues and Perspectives Köln; Rüdiger Köppe Verlage pp 87-96.

[9] Payne, T. E (1997) Describing Morphosyntax: A Field Guide for Linguists. Cambridge, Cambridge University Press.

[10] Haiman, J. (1983) Iconic and Economic Motivation. In Language Vol. 59. No. 4 pp. 781-819.

[11] Haspelmath, M. (2008) Alienable vs Inalienable possessive Constructions. https//www.eva.mpg.de/lingua/conference/08.../pdf/...Haspel manth_possessives.pdf.

[12] Heine, B. (1997) Possession: Cognitive sources, forces and grammaticalization. Cambridge; Cambridge University Press.

[13] Stassen, L. (2009) Predicative Possession. Oxford; Oxford University Press.

[14] Tham, S. W. (2013) Possession as a non verbal predication. Berkeley Linguistics Society 39: 302-316.

[15] Sikuku, J. M \& J. M. Wanyonyi (2018) On the nature of possession in Keiyo. Schroeder H. \& P. Jerono (eds) NiloSaharan Issues and Perspectives. Köln; Rüdiger Köppe Verlag pp. 135-147. 